the divinity as a sublime mechanic who not only inhabited the universe but who also needed to be defended by thinkers increasingly immersed in the problem of "theodicy." To see this tradition as characteristic of "the ancient and medieval perception of the supernatural," as Joan-Pau Rubiés asserts in an otherwise exceptionally illuminating essay (130), is an unfortunate misconception that will do little to help overcome what Bulman describes as "an intrinsically intractable and inappropriate debate that has, ironically enough, taken on the character of a confessional conflict" (31).

Fernando Cervantes

University of Bristol

\title{
Robeson Taj Frazier, The East is Black: Cold War China in the Black Radical Imagination (Durham: Duke University Press, 2014). 328pp. Paper- back $\$ 26.95$.
}

The East is Black by the African American studies and media studies scholar Robeson Taj Frazier is a cutting-edge book which succeeds both as theory and as history. Interdisciplinary and well-written, this monograph provides brilliant insight into the possibilities and limitations of black radical global imaginaries through an examination of black American encounters with Communist China from 1949 to 1976. The author vividly traces the travels, writing, and teaching in the People's Republic of China (PRC) of the preeminent black scholar W.E.B. Du Bois, playwright and activist Shirley Graham Du Bois, journalist William Worthy, freedom fighters Robert F. Williams and Mabel Williams, and Marxist feminist Vicki Garvin during the height of the global Cold War. Frazier's book distinguishes him as an important new voice on black radicalism, black internationalism, the Cold War, and Afro-Asian encounters, in the vein of Fred Ho, Vijay Prashad, Diane Fujino, Gerald Horne, Bill Mullen, and Judy Tzu-Chun Wu.

The book takes the first part of its title from a Chinese opera and song "Dong Hong" ("The East is Red"). The song briefly served as the Chinese national anthem during the 1960s and it captured the revolutionary elan of the PRC. Framing itself as the champion of formerly colonized people of colour and as an opponent of the United States and the Soviet Union, China under Mao Zedong - the revolutionary, chairman of the Chinese Communist Party, and founder of the PRC in 1949-publicly supported African American liberation struggles and Third World solidarity during the 1950s and 1960s. This stance captured the imagination of black radicals - they viewed Jim Crow and anti-black violence at home as the Achilles Heel of U.S. Cold War global policy that sought to win the hearts and minds of emerging Third World nations against communism. For black American radicals, China symbolized freedom and international solidarity. For these reasons, they came to see the PRC for themselves—-the Du Boises and William Worthy sojourned to 
China in the 1950s, while Robert Williams and Mabel Williams, the militant civil rights leaders from North Carolina who advocated armed defense and fled the United States first for Cuba and then to China, and Vicki Garvin who lived in the PRC for years during the 1960s.

Analytically, Frazier's work extends and recasts what historian Robin D. G. Kelley has called the "black radical imagination." Kelley uses the term to describe the varied ways African-descended activists, writers, and artists have dreamed of a new world different from the status quo. According to Kelley, the imagination, not racism, misery, and exploitation, served as the catalyst for political engagement and social transformation. For Frazier, "[i]magining here is thus displayed as a process of ideology that marshals and deploys cognitive faculties, consciousness, and social life for the process of contesting the worlds we inhabit and making and shaping them anew" (7). While the book calls attention to the achievements of black-Chinese solidarities, the author is especially concerned with interrogating the "inconsistencies and failings of ... relations between black and Chinese radicals- the disjunctive and ambivalent contours of transnational radical imaginings" (17).

Media provides a key lens for Frazier's examination of the "dissonance of imagining" and "limitations and misunderstandings" of black-Chinese solidarities $(10,41)$. Charging that black and Chinese radicals perceived the Cold War and Third World as discursive sites of struggle, the author looks at media, visual culture, travel narratives, and political communications of black radical travelers, and cultural representations of the African-descended produced by the PRC. Conflicting political agendas, national and cultural differences, miscommunications, and opportunism shaped media and representations produced by black and Chinese radicals, revealing the "unevenness and inevitable points of friction" within this radical global transnational project (17).

The East is Black is exceptionally strong in its discussion of the gendered contours of black-Chinese solidarities. Unlike many recent studies of black internationalism that provide only cursory discussion about women and gender, Frazier focuses significant attention to "the influence of attitudes and structures of gender on both Chinese and black radical constructions of racial internationalism and anticapitalist struggle" (11). The book brings to life the transnational activism and journeys of Shirley Graham Du Bois, Mabel Williams, and Vicki Garvin.

Frazier is at his best in shedding new light on the dynamic life and transnational work in China of Vicki Garvin. By tracing Garvin's work in the PRC as an English teacher, Frazier illustrates the possibilities and complexities of black-Chinese solidarities, black expatriate life, and Chinese communism. During the 1950s, Garvin was an active leader in the Harlem Communist Party and the Black Left. Garvin broke from the Communist Party in 1958, and eventually made her way to Africa by the early 1960s. In Ghana, she emerged as a leader of the African American expatriate community in the nation's capital: Accra. While in Ghana she came to know Huang Hua, the Chinese ambassador to the West African republic, who, 
along with his spouse-fellow diplomat He Liliang-encouraged Garvin to teach English in China. After arriving in the PRC in 1964, she worked as an English-language instructor, taught courses in African American history, and worked for a government-run publishing house. She witnessed the Great Proletarian Cultural Revolution (Cultural Revolution), an ambitious plan launched in 1966 by Mao Zedong that was intended to build a new socialist society yet led to the death of millions of Chinese.

Personally, Garvin's highly-publicized marriage in China to Leibel Bergman, a white American and ex-Communist Party member, symbolized the ways the PRC created possibilities for interracial marriage and brotherhood that were denied in the United States. At the same time, her work revealed the limits of radical global solidarities and Chinese communism. The Chinese state limited the travel of expatriates like Garvin and lavished them with accommodations unknown to most ordinary Chinese citizens. As privileged outsiders mindful of their precarious place in China, Vicki Garvin, Robert Williams, and other black Americans in the PRC failed to formulate a "balanced examination of the internal struggles and contradictions that were rampant in the Chinese state and society," asserts Frazier (161). Ultimately, Garvin returned to the United States in 1970. However, she continued to support and to visit the PRC even as China pursued a diplomatic rapprochement with the United States, downplayed the world revolution, and forged neo-colonial relationships with African states during the 1970s.

Meanwhile, Frazier closely examines the masculinist and heteronormative framings of communism, black liberation, and global solidarities articulated by black male radicals in China like W.E.B. Du Bois and Robert Williams. Even though he praised the PRC for allegedly improving the status of women, Du Bois often relied on "masculine metaphors and examples" to describe Chinese communism (52). According to Frazier, "Du Bois's representation of [Chinese] Communism was thus gender specific, denoting male activity, male knowledge, and a geopolitics as a site of male struggle" (53). Similarly, the PRC, despite its anti-sexist rhetoric, promoted policies that subordinated women. So while China helped black male radicals to envision a world without racism and capitalism, they were less successful in transcending the masculinism and patriarchy of their day.

The postscript provides useful insight into Frazier's own intellectual and personal journey to, and encounters with, China. In the late 1990s, he studied in Beijing as an exchange student and lived with a Chinese host family. Like the subjects of his book, living in the PRC transformed the author. While overseas, he came to appreciate the harrowing experiences of the Chinese people living under the Cultural Revolution. He also witnessed the ways media and cultural practices promoted racist representations of African Americans. He departed China "concerned with how regimes of representation and power travel and take shape in different environments, particularly with how ideologies of race are articulated in media, the movement of bodies, and cultural production, and to whose ends" (216). Clearly, 
travelling to the PRC prompted Frazier to rethink the world and his place within it. An important takeaway from the postscript is the author's emphasis on the significance of global travel for broadening one's horizons. His time in China provides important lessons for African diaspora studies. The author's proficiency in Chinese and his time overseas speaks to the importance of language training and international travel for scholars of the African diaspora.

East is Black is not without its gaps. It would have been interesting if the author had discussed whether black women radicals forged a collective radical feminists of colour community while in the PRC. Also, the impact of Communist China on black radicals and African American communities in the United States receives only cursory discussion in the book. Granted this book is focused on African Americans in China. Still, it would have been useful to look at the global imaginaries of China for black radicals in the United States, especially given the importance of Mao's Little Red Book to the Black Panther Party. However, these are minor quibbles. The East is Black is a remarkable study of African American encounters in Communist China, the global Cold War, the politics of media and representation, the gendered contours of black internationalism, and the possibilities and limits of transnational radical political solidarities. Given that humanity faces an existential crisis and that the world is becoming increasingly globalized, The East is Black provides a road map for (re)imagining radical global solidarities devoid of the romantic and masculinist view of our predecessors.

Erik S. McDuffie

University of Illinois at Urbana-Champaign

\section{Sarah Turnbull, Parole in Canada: Gender and Diversity in the Federal System (Vancouver: UBC Press, 2016). 244pp. Hardcover \$99.00.}

Conditional release offers prisoners the opportunity to be released from custody to serve the remainder of their sentence in the community under supervision and with conditions. The intention is that gradual release into the community with some assistance fosters reintegration and encourages success in the community. The decision to release on parole, however, is a discretionary one, with concerns about risk and a desire to protect public safety dominating the decision-making process. The constitution of Canada's correctional population is changing, raising questions about how to best adapt to an increasingly diverse population. Using the Parole Board of Canada (PBC) as a case study, Turnbull explores the ways in which diversity, gender, Aboriginality, and race are defined, understood, and incorporated into conditional release practices. Positioning diversity as something to be managed, Turnbull argues that the PBC selectively includes certain aspects of diversity in the assessment of risk when making conditional release decisions. While noting the efforts made to address a changing prisoner demographic, Turnbull draws our atten- 